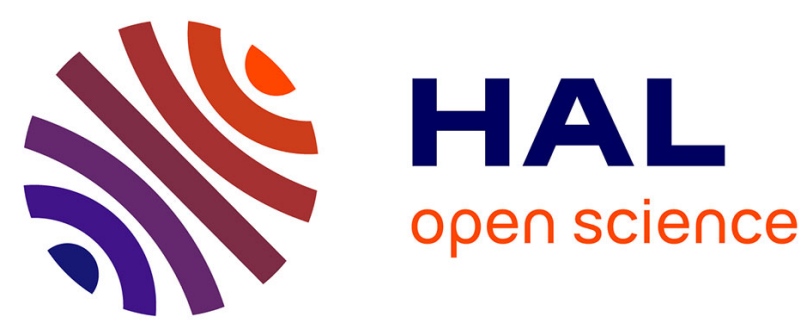

\title{
Prediction of September-December Fire in New Caledonia (Southwestern Pacific) Using July Niño-4 Sea Surface Temperature Index
}

Vincent Moron, Renaud Barbero, Morgan Mangeas, Laure Borgniet, Thomas Curt, Laure Berti-Équille

\section{To cite this version:}

Vincent Moron, Renaud Barbero, Morgan Mangeas, Laure Borgniet, Thomas Curt, et al.. Prediction of September-December Fire in New Caledonia (Southwestern Pacific) Using July Niño-4 Sea Surface Temperature Index. Journal of Applied Meteorology and Climatology, 2013, 52 (3), pp.623 - 633. 10.1175/JAMC-D-12-03.1 . hal-01855547

\section{HAL Id: hal-01855547 \\ https://hal.inria.fr/hal-01855547}

Submitted on 25 Oct 2021

HAL is a multi-disciplinary open access archive for the deposit and dissemination of scientific research documents, whether they are published or not. The documents may come from teaching and research institutions in France or abroad, or from public or private research centers.
L'archive ouverte pluridisciplinaire HAL, est destinée au dépôt et à la diffusion de documents scientifiques de niveau recherche, publiés ou non, émanant des établissements d'enseignement et de recherche français ou étrangers, des laboratoires publics ou privés.

\section{(c)(1)}

Distributed under a Creative Commons Attribution| 4.0 International License 


\title{
Prediction of September-December Fire in New Caledonia (Southwestern Pacific) Using July Niño-4 Sea Surface Temperature Index
}

\author{
VINCENT MORON \\ Aix-Marseille Université, CEREGE UM 34 CNRS, Aix en Provence, France, and International Research Institute \\ for Climate and Society, Columbia University, New York \\ RENAUD BARBERO \\ Aix-Marseille Université, CEREGE UM 34 CNRS, Aix en Provence, France \\ MORGAN MANGEAS \\ Espace, IRD, Nouméa, New Caledonia, France \\ LAURENT BORGNIET AND THOMAS CURT \\ IRSTEA, UR EMAX, Aix en Provence, France \\ LAURE BERTI-EQUILLE \\ CEREGE UM 34 CNRS, Aix en Provence, France
}

(Manuscript received 17 December 2011, in final form 11 September 2012)

\begin{abstract}
An empirical statistical scheme for predicting September-December fires in New Caledonia in the southwestern Pacific Ocean region using a cross-validated generalized linear model has been developed for the 2000-10 period. The predictor employs July sea surface temperatures (SST) recorded over the Niño-4 box $\left(5^{\circ} \mathrm{S}-5^{\circ} \mathrm{N}, 160^{\circ}-210^{\circ} \mathrm{E}\right)$, which are closely related to austral spring (September-November) rainfall anomalies across New Caledonia. The correlation between the logarithm of observed and simulated total burned areas across New Caledonia is 0.87. A decrease in the local-scale skill (median correlation between the log of observed and simulated total burned areas in a $20-\mathrm{km}$ radius around a rain gauge $=0.46$ ) around the main town (Nouméa) and its suburbs in the southwest of Grande Terre, and also in northern New Caledonia, could be associated either with a weaker climatic forcing from the Niño-4 SST index or a small-scale climatic forcing not linearly related to the El Niño-Southern Oscillation (ENSO) phenomenon. It is more likely that the decrease is tied to the influence of human-driven factors that blur the regional-scale climatic signal mostly associated with central Pacific ENSO events.
\end{abstract}

\section{Introduction}

New Caledonia (NC) is a subtropical archipelago in the southwestern Pacific Ocean $\left(\sim 21.5^{\circ} \mathrm{S}, 165.5^{\circ} \mathrm{E}\right)$ comprising a main $400 \mathrm{~km} \times 50 \mathrm{~km}$ island (Grande Terre) and smaller islands. New Caledonia is considered to be a major biodiversity hot spot, that is, "an area

Corresponding author address: Pr. Vincent Moron, CEREGE UM 34 CNRS, Europôle méditerranéen de l'Arbois, BP 80, Aix en Provence F-13545, France.

E-mail: moron@cerege.fr featuring exceptional concentrations of endemic species and experiencing exceptional loss of habitat" (Myers et al. 2000). The ecological threat identified in various ecosystems (Bouchet et al. 1995; Jaffré et al. 1998; Gillespie and Jaffré 2003) results from factors that include land clearance, grazing, and natural and humandriven fires (Chevalier 1996; McCoy et al. 1999). The seasonal peak in fires in NC occurs near the end of the dry season from September to December (Barbero et al. 2011, hereinafter B11), when increased temperatures may be associated with dried organic soils and surface fuels. 
B11 recently demonstrated that the occurrence of fire increased with antecedent short-term to medium-term (3 month) droughts. Numerous studies (Morlière and Rébert 1986; Nicet and Delcroix 2000; Fischer et al. 2004) have already demonstrated that warm El NiñoSouthern Oscillation (ENSO) events are associated with negative rainfall anomalies, mostly through the anomalous northeastward shift of the South Pacific convergence zone (SPCZ; see Vincent 1994). Barbero and Moron (2011) showed also that warm ENSO events with larger sea surface temperature (SST) anomalies (SSTA) located in the central Pacific, which are usually referred to as Modoki (Ashok et al. 2007) or central Pacific events (Kao and Yu 2009), have a larger impact on NC rainfall, especially in September-November (SON), than do those that exhibit warmer SSTAs in the eastern Pacific, such as the major events of 1982/83 and 1997/98. The September-December (SOND) season thus combines a strong ENSO forcing on the rainfall anomalies across NC with the main fire season in NC. These factors suggest a good predictability of the fire from ENSO SSTA indices for which polarity is usually firmly established 3-6 months ahead, which is approximately from the "boreal spring barrier" when ENSO usually switches from one state (warm, cold, or neutral) to another (Balmaseda et al. 1995). The ENSO state is then usually stable from at least austral winter to the end of the next austral summer, thus including the main fire season (SOND) in NC.

The purpose of this paper is to extend and complete the previous analyses of B11, which described the statistical relationship between active fires from Moderate Resolution Imaging Spectroradiometer (MODIS) measurements taken from the Aqua and Terra satellites (van der Werf et al. 2008) and the antecedent local-scale atmospheric anomalies across NC. B11 concluded that the interannual variability of the SOND frequency of MODIS-detected active fires is strongly related to synchronous and antecedent seasonal local-scale rainfall anomalies. In particular, B11 obtained a correlation of 0.78 between monthly anomalies of all active MODIS hot spots observed across NC in SOND and the June-August Niño-3.4 SST index using a second-order polynomial fit. In that context, the ENSO phenomenon is a potentially valuable source of predictability of seasonal fire frequency and/or extent (Fig. 11 in B11), since warm ENSO events are associated with anomalous drought in NC from August. We extend the B11 analysis to 2010, and the MODIS active fires are checked with independent satellite estimates of vegetation changes provided by the MODIS "MOD13Q1" (hereinafter MOD13Q1) product and Landsat-7 Enhanced Thematic Mapper plus (hereinafter ETM+). Moreover, our study explores the feasibility of SOND fire prediction with a simple statistical model using a January-September Niño-4 SST index, since Barbero and Moron (2011) indicated that central Pacific SST indices are the best potential predictors of NC seasonal rainfall anomalies in austral spring. Note that the month with the highest predictability (i.e., July) is examined in more detail. The seasonal fire extent is forecast at regional scale [defined as total burned area across NC (hereinafter BANC)] and also at local scale (the burned area in a $20-\mathrm{km}$ radius around a rain gauge). Our basic hypothesis is that seasonal predictability conveyed by ENSO phenomena operates at a larger scale than the area of $\mathrm{NC}$, but it is also crucial to evaluate how this potentially predictable signal is scaled toward localized areas and combined with other factors, since it is well established that human-driven effects depending, for example, on population density and socioeconomic practices, are not necessarily homogeneous at the NC scale.

\section{Data and methods}

\section{a. Burned areas}

First, data on fire activity from March 2000 to December 2010 were derived from Terra-Aqua MODIS active fire data products (Giglio et al. 2006). The database is available online from the Fire Information for Resource Management System (FIRMS) Fire Mapper (http://earthdata.nasa.gov/data/nrt-data/firms/active-firedata), which provides current and historical active fire data and monthly burned area and delivers near-realtime active fire data. The characteristics of the MODIS sensors (thermal information at 1-km spatial resolution) and the frequency of acquisition ( 2 times per day by each sensor: one daytime observation and one nighttime observation) are considered to be accurate to avoid cloud interference on fire detection. MODIS detected a total of 1370 active fires during the $2000-10$ period. The occurrence of fire is checked using a vegetation index derived from composited reflectance data in MOD13Q1 and ETM+, following Roy et al. (2008), who showed a marked difference between MODIS burned areas (from MOD13Q1) and active fires in three vegetation classes mostly affected by fire in Australia (open shrublands, savannas, and grasslands). The analysis of vegetation indices (normalized difference infrared index and normalized burn ratio) in MOD13Q1 (horizontal resolution of $250 \mathrm{~m}$; time sampling $=16$ days) and ETM+ (horizontal resolution $=30 \mathrm{~m}$; three or four images per year) allowed us to identify changes in vegetation due to fire. The images used to check MODIS hot spots were usually separated in time by only several weeks, with 
a 3-month maximum for the MOD13Q1 product. This time interval is considered to be short enough to obtain a realistic detection of burned areas (at least for fires of larger than $\sim 6 \mathrm{ha}$ ). The use of high-resolution ETM + confirms the detection of most of the fires using MOD13Q1. From this double-check method, $44 \%$ of fires detected with MODIS "active fires" are validated and are used as a fire database for the following statistical analyses.

A filtering algorithm was used to remove multiple counts of the same fire, defined as covering an area larger than a single pixel $\left(1 \mathrm{~km}^{2}\right)$ and also appearing in two successive images. This iterative algorithm aggregates hot spots when they occur less than $1 \mathrm{~km}$ apart and in the same 24-h time period. It allows extracting distinct fires and also their duration and areal extent. The final dataset includes the perimeter of each fire and its total area (total burned area across $\mathrm{NC}=26132$ ha as compared with the total area of Grande Terre of $16346 \mathrm{~km}^{2}$ ).

\section{b. Rainfall data}

Of the 118 rain gauges in NC operated by MétéoFrance, we selected 70 rain gauges having less than $20 \%$ of missing entries for the period 2000-10. Îles Loyauté (Loyalty Islands) are excluded from the database since fires are rare there in the MODIS database (B11) and are not included in the checking with MOD13Q1 and $\mathrm{ETM}+$. There are only $5.6 \%$ of missing entries in the database of the 70 rain gauges. Note that the mean burned area across $\mathrm{NC}$ reaches its maximum around the transition between the dry season and the wet season between September and December and that a secondary peak occurs in April-May near the beginning of the dry season (Fig. 1a). The seasonal drought is less intense along the windward coast, related to the orographic forcing of the near-constant east-southeast Alizean flow, and also usually in the extreme southern part of $\mathrm{NC}$, related to possible wintertime rainfall (Fig. 1b).

\section{c. Sea surface temperatures}

Monthly SST have been extracted from the "Extended Reconstructed SST Dataset" (http://iridl.ldeo.columbia. edu/SOURCES/.NOAA/.NCDC/.ERSST/.version3b/) from January 2000 to December 2010 (Kaplan et al. 1998). The Niño-4 SST index is the average of monthly SSTAs over $5^{\circ} \mathrm{S}-5^{\circ} \mathrm{N}, 160^{\circ}-210^{\circ} \mathrm{E}$.

\section{d. Methods}

Our main goal is to predict SOND burned areas at local and NC scales. The SOND burned areas are localized around each rain gauge. This choice is relevant since rain gauges are concentrated in inhabited areas and most of the fires are ignited by people. It allows also an easy comparison between interannual variability of seasonal burned areas and rainfall, which is the main climatic driver here (B11). We computed the mean SOND burned area ( $=75.5 \%$ of the annual burned area) in a $20-\mathrm{km}$ radius around each rain gauge (Fig. 1c). Approximately $90 \%$ of the fires' perimeters are fully included in a $20-\mathrm{km}$ radius around a given rain gauge. When the $20-\mathrm{km}$ radius intersects a fire, the percentage of the perimeters closer to $20 \mathrm{~km}$ from a given rain gauge is used to estimate the percentage of the fire allocated to this rain gauge. This is a simple method to divide usually complex shapes. The highest mean burned area is clearly observed around Nouméa (Fig. 1c), but this mostly reflects the largest fire, called the Montagne des Sources fire (MdS hereinafter), which burned 3641 ha $(13.9 \%$ of the total burned surface in 2000-10) in December of 2005. The mean burned area is usually larger along the leeward drier coast, especially between Voh and Poya and around La Foa (Figs. 1b,c).

A rain gauge (Yate/La Ouinne; Fig. 1b) along the windward coast is discarded from the following analyses since burned area is equal to 0 there. We also removed redundant information due to distance since closely situated rain gauges, especially around Nouméa and its suburbs, may usually share the same fires and there is a risk of overrepresenting well-documented areas from the meteorological point of view. The correlations between the logarithm of SOND burned areas are computed among the remaining 69 rain gauges, and we seek iteratively those groups of rain gauges that combine a correlation of $>0.95$ and a mean distance of $<20 \mathrm{~km}$. Only data for rain gauges associated with the largest mean burned area in each group are retained in the analysis, reducing the set from 69 to 43 rain gauges.

The next step is to perform an empirical orthogonal function (EOF) analysis to extract coherent variations that are dominant among the local-scale burned areas (Gedalof et al. 2005), with the leading EOF being the pattern most frequently realized without the constraint of any particular analytic form. An EOF analysis is then computed on the standardized anomalies (zero mean and unit variance) of the log of SOND burned area in a radius of $20 \mathrm{~km}$ around the 43 rain gauges. The robustness of the EOF is carefully checked because the time period is short.

To assess the significance of the eigenvalues, we constructed a matrix of 43 random-phase time series. Each random time series has the same spectral power, but with random phase, as the original time series of standardized log of the burned areas (Janicot et al. 1996; Ebisuzaki 1997). This process is repeated 1000 times, and the corresponding eigenvalue spectrum is compared 
(a) Monthly mean burned area

\& 70-station rainfall

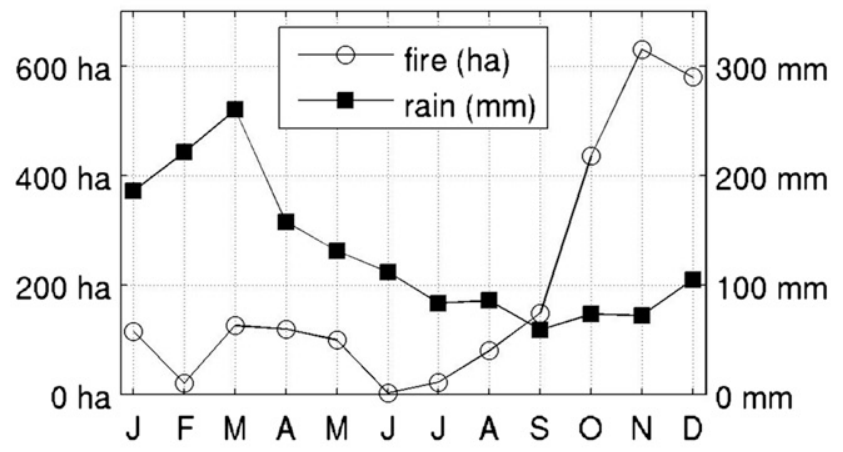

(b) Mean rainfall (in $\mathrm{mm} /$ day) in July-November

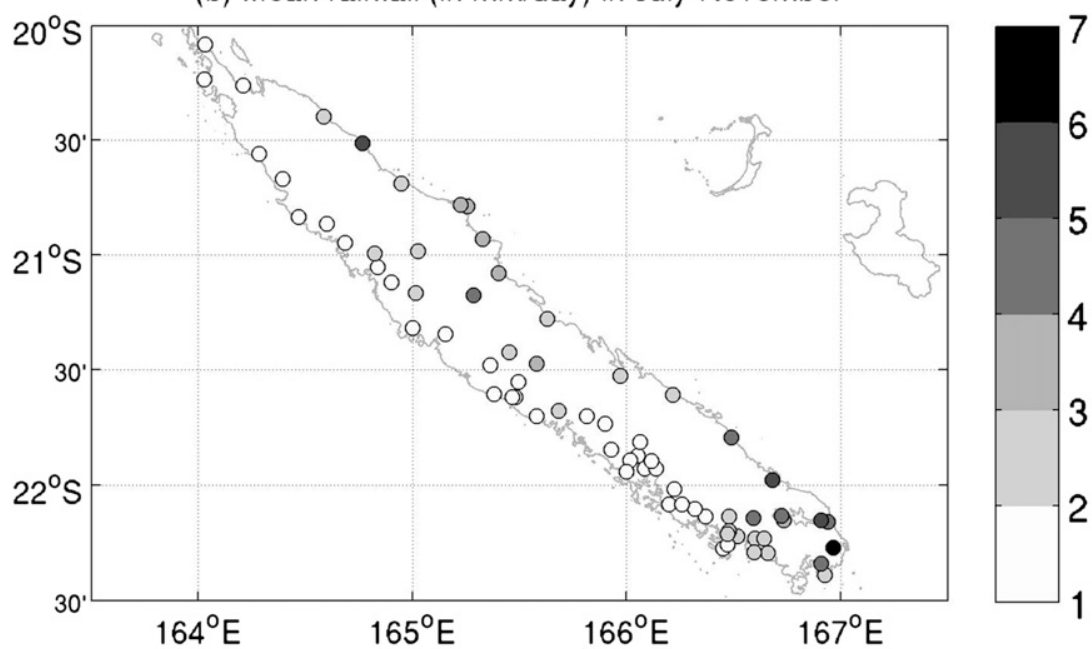

(c) Mean burned area (in ha) in a $20-\mathrm{km}$ radius around rain gauge (SOND)
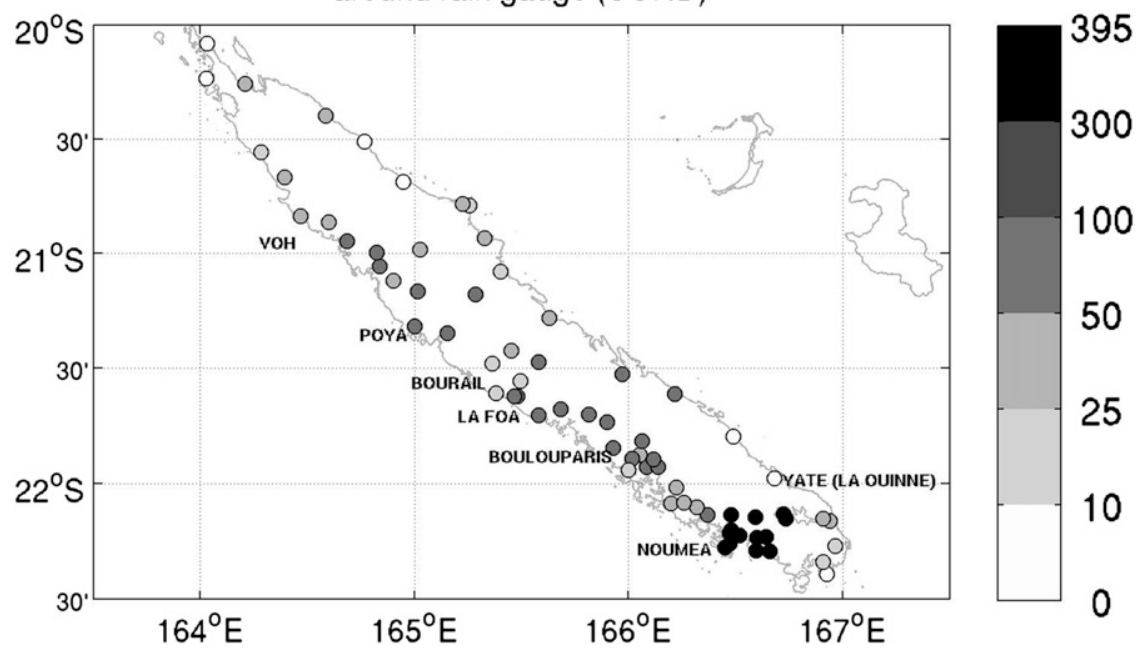

FIG. 1. (a) Monthly mean (2000-10) burned area (line and open circles) and rainfall averaged over the 70 rain gauges (line and filled squares) spatially averaged across NC. (b) Mean rainfall $\left(\mathrm{mm} \mathrm{day}^{-1}\right.$ ) in July-November. (c) Mean burned surface (ha) in a 20-km radius around the 70 rain gauges in September-December. The names and locations of several rain gauges used in the main text are indicated in (c). 
(a) Eigenvalues of log (burned area)

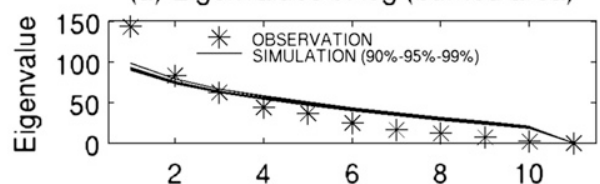

(b) EOF\#1 (var. = 33.3\%)

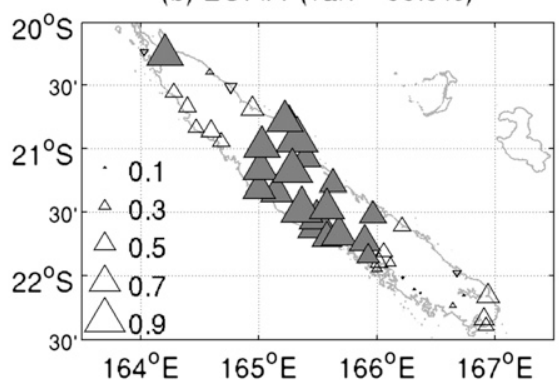

(c) EOF\#2 (var. = 19.3\%)

(d) PC\#1, PC\#2 and NC

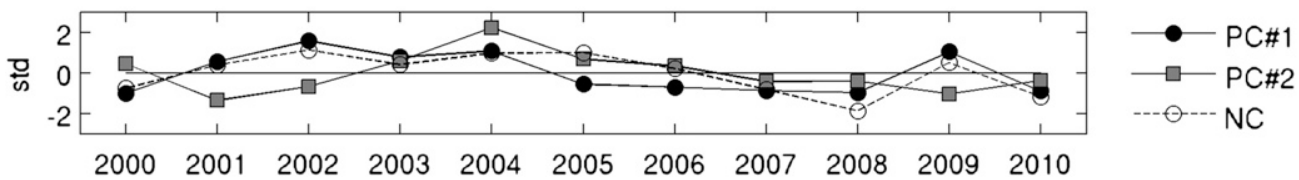

FIG. 2. (a) Eigenvalue spectrum (asterisks) with $90 \%, 95 \%$, and $99 \%$ levels of significance (black line) estimated by a Monte Carlo simulation (1000 iterations). (b) First and (c) second EOFs of the standardized anomalies of the log of SOND burned area in a $20-\mathrm{km}$ radius around 43 rain gauges (see text). The EOFs are displayed as loadings, i.e., correlation between the log of SOND burned area and the PCs. In (b) and (c), upward-pointing (downward pointing) triangles indicate positive (negative) correlations and gray (open) triangles indicate significant (not significant) correlations at the two-sided $90 \%$ level according to a random-phase (Janicot et al. 1996) test. (d) First and second PCs standardized to zero mean and unit variance together with the standardized anomalies of the log of the total SOND burned area in NC.

with the observed spectrum (Fig. 2a). Next, we recomputed EOF using only a randomly chosen half of the 43 rain gauges. This was also repeated 1000 times so that the robustness of the significant principal components (PC) could be assessed.

The prediction model is performed using a generalized linear model (GLM). A first GLM is fitted with July Niño-4 SST index as the predictor and BANC as the response variable. A log link is used to take into account the exponential increase in fires during warm central Pacific events (see Fig. 11 of B11). The model is cross validated (Michaelsen 1987); that is, the parameters are iteratively estimated using 10 training years and they are used to hindcast the last season, and this process was repeated 11 times. It is difficult to apply this model directly to the seasonal burned area summed over a radius of $20 \mathrm{~km}$ around each rain gauge since the many zeros $(65 \%$ of the dataset) frequently, cause the GLM weights to be ill conditioned. To avoid that, we trained the model using a sample of stations instead of a single station. For that, we selected the 38 rain gauges at which at least two SOND seasons include a fire in a radius of $20 \mathrm{~km}$. A constraint of two seasons instead of one is needed because of the cross validation (i.e., a model could not be fitted if values are always equal to zero). Then, an individual cross-validated GLM for each target is fitted using the rain gauge having similar burned area in mean (with a tolerance of $\pm 1 / 2$ of the standard deviations of the mean burned area in SOND relatively to the target; i.e., $\sim 40 \mathrm{ha}$ ) and having also a positive correlation of the $\log$ of burned areas during the training period. About 20 stations on average fulfill both criteria, and the fitting is thus done on average on 10 training years $\times 20=200$ values instead of 10 .

Last, all correlations are tested using a random-phase test (Janicot et al. 1996) with an asterisk indicating a significant correlation level of $99 \%$ (two sided) hereinafter. Note that the $99 \%$ confidence interval is equal to $0.04-0.93($ correlation $=0.70), 0.27-0.96($ correlation $=$ 0.80 ), and $0.57-0.98$ (correlation $=0.90$ ) for a sample size of 11 observations.

\section{Results}

\section{a. Interannual variability of fire and its relationship with SST}

Because we hypothesize that SOND burned areas are related to rainfall anomalies in austral spring, which are 
partly forced by the ENSO phenomenon, it is important to assess the spatial coherence of burned areas, especially to investigate whether the leading EOF is homogeneous across NC. The eigenvalue spectrum shown in Fig. 2a indicates that the two leading modes, accounting for $33.3 \%$ and $19.3 \%$ of the total variance, are significant at the one-sided $99 \%$ level (Fig. 2a). The first EOF is characterized by a homogeneous pattern with the largest loadings mostly in the center of Grande Terre (Fig. 2b), and the second EOF shows positive loadings along the leeward coast, Nouméa, and also near Voh (Fig. 2c). Figure $2 \mathrm{~d}$ shows that the first $\mathrm{PC}$ reflects BANC well (correlation coefficient $r=0.76^{*}$ between the log of BANC and PC1), and that the second PC is independent of it ( $r=0.26$ between the $\log$ of BANC and PC2). The robustness of the two leading PCs is tested by repeating the EOF 1000-time analysis on a subset of 23 randomly chosen rain gauges. The correlation between PC1 from the 43 rain gauges and from the subset of 23 rain gauges is $0.95^{*}$ on average without any switch from the first rank. PC2 rarely appears at the third rank $(15 \%$ of the 1000 subsets) but is always very similar to PC 2 of the entire dataset $\left(\right.$ mean correlation $\left.=0.85^{*}\right)$. Despite the shortness of the record, the leading two PCs are robust and are not too sensitive to spatial sampling.

Figure 3a shows the correlation between the log of BANC and the July SST. The correlation pattern exhibits a clear ENSO pattern with large positive correlation around the Niño-4 box (black dashed rectangle in Fig. 3a) surrounded by a horseshoe of negative correlations, reflecting a high sensitivity to central Pacific events (Kao and Yu 2009; Barbero and Moron 2011). This lagged relationship is due to the temporal persistence of SST from austral winter to spring $\left(r=0.90^{*}\right.$ between Niño-4 SST index in July and that of the following October in 2000-10) and its dynamical forcing on $\mathrm{NC}$ rainfall anomalies that are connected to the burned areas. Figure $3 \mathrm{~b}$ shows that the correlation between monthly Niño-4 SST index and log of BANC is already significant in May, that is, after the "spring predictability barrier" (Balmaseda et al. 1995), and is constantly above $0.80 *$ from June onward (maximum $=0.92 *$ in July). Note that the correlations between July Niño-4 SST index and the $\mathrm{PC} 1$ and -2 of the SOND burned areas are, respectively, $0.84 *$ and 0.14 . This is fully consistent with the hypothesis that $\mathrm{PC} 1$ conveys the main regional-scale predictable signal related to the central Pacific ENSO phenomenon. We need to be cautious about the extremely high correlations because of the shortness of the available record. We thus checked this correlation with the active hot spots detected by the Along-Track Scanning Radiometer, algorithm 2 (ATSR-2), and Advanced Along-Track Scanning Radiometer (AATSR) sensors
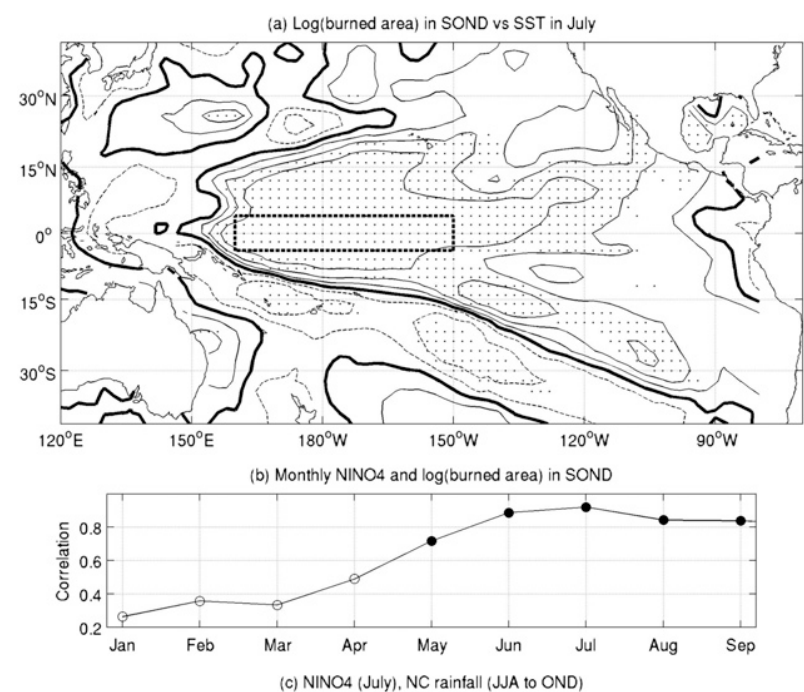

(c) NINO4 (July), NC rainfall (JJA to OND

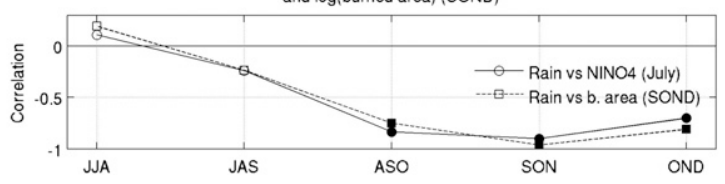

FIG. 3. (a) Correlation (negative $=$ dashed lines, positive $=$ solid lines, and $0=$ thick solid line, with contour interval of 0.25 ) between the log of seasonal (SOND) burned area across all NC and SST in July. (b) Correlation between monthly value (from January to September) of the Niño-4 SST index and the log of total burned area across NC. (c) Correlation between running 3-month standardized anomaly index (=spatial average of localscale standardized anomalies) of NC rainfall (from June-August to October-December) with July Niño-4 SST index and the log of seasonal (SOND) burned area. The dots in (a) and filled symbols in (b) and (c) are significant correlations at the two-sided $90 \%$ level according to a random-phase test (Janicot et al. 1996).

(Le Page et al. 2008) and covering the SOND seasons from 1995 to 2011 (available online in the World Fire Atlas at http://due.esrin.esa.int/wfa/). Because of the limited temporal sampling and the fact that ATSR-2 and AATSR record only nighttime fires, only 63 hot spots were detected across NC during the 17 available SOND seasons (from 0 in 1998 to 8 in 1997). Despite this very limited sampling, the correlation between the SOND frequency of hot spots and July Niño-4 SST index is equal to $0.75^{*}$, which is largely consistent with the values found using MODIS and Landsat datasets. In comparison, the correlation between total ATSR/AATSR hot spots and $\log$ of BANC $=0.82 *$ during SOND 2000-10.

The relationship between 3-month rainfall anomalies and the $\log$ of BANC on one hand and between 3-month rainfall anomalies and July Niño-4 SST index on the other hand follows the same seasonal modulation, peaking in SON (Fig. 3c). This seasonal modulation is partly explained by the cycle of warm central Pacific ENSO events (Barbero and Moron 2011). To summarize, 
(a) Observed and simulated burned area across NC

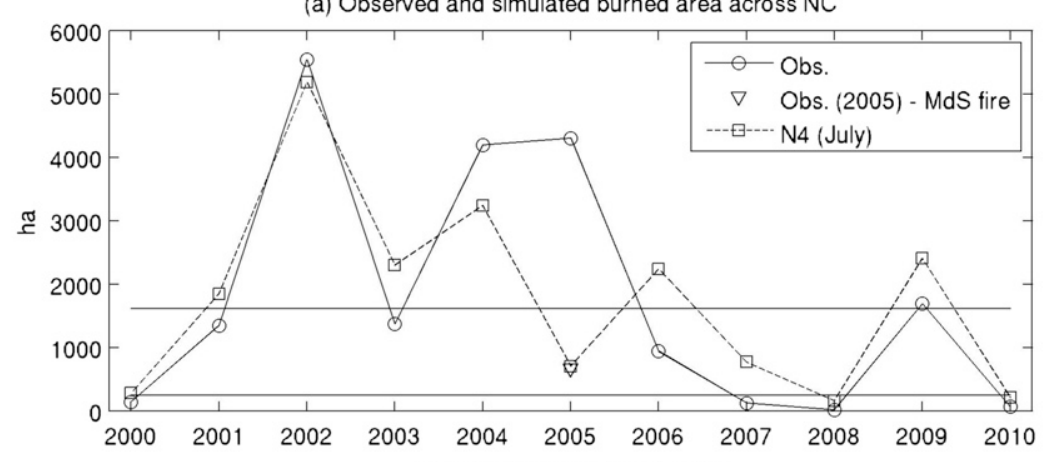

(b) XV Skill from NINO 4 (July)

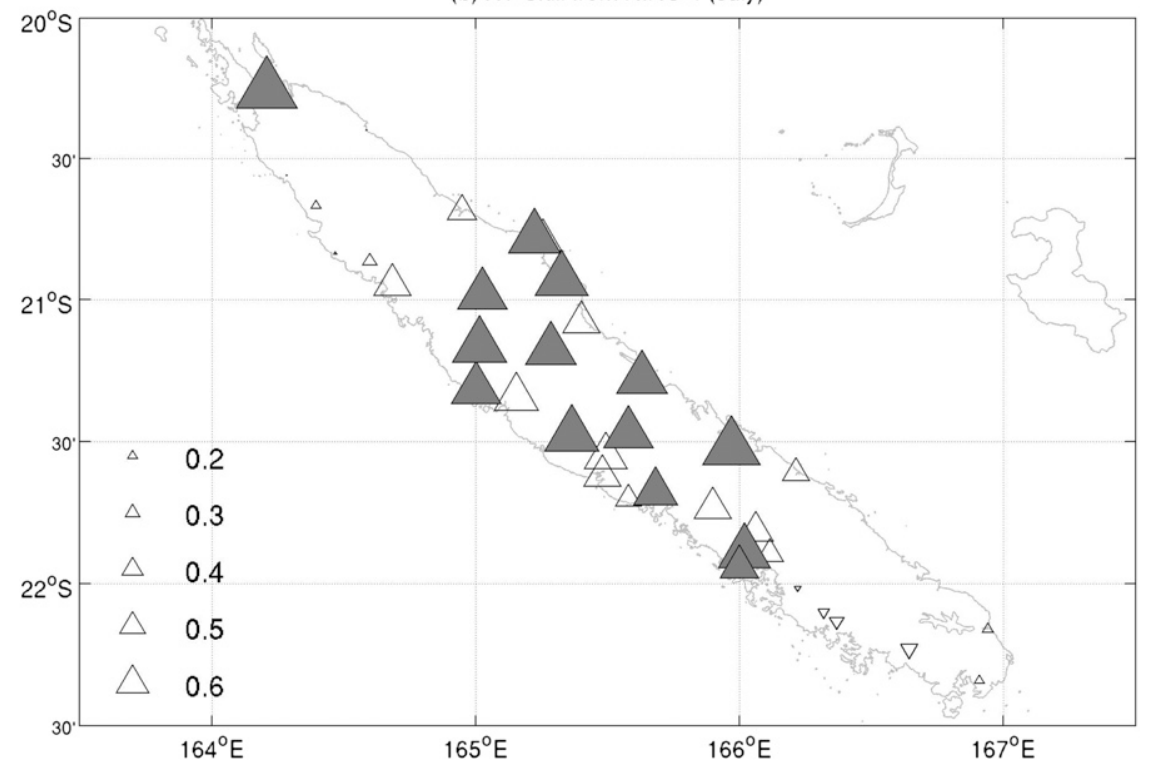

FIG. 4. (a) Observed (solid line with circles) burned area across all of NC in SOND with the cross-validated simulated model (dashed line with squares) from the July Niño-4 SST index using a GLM with a log link. Horizontal lines are the upper and lower observed terciles. (b) Correlation between observed and simulated SOND burned area in a 20-km radius around 38 rain gauges. Upward-pointing (downward pointing) triangles indicate positive (negative) correlations, and gray (open) triangles indicate significant (not significant) correlations at the two-sided $90 \%$ level according to a random-phase test (Janicot et al. 1996).

a warm central Pacific ENSO event (as in 2002,2004, or 2009), starting from austral autumn grows from austral winter to austral summer and lowers rainfall across $\mathrm{NC}$ in austral spring, mostly through the anomalous NE shift of the SPCZ (Vincent 1994; Vincent et al. 2011; Barbero and Moron 2011), increasing the probability of fire occurrence in that area. Even for short time periods, the level of correlation allows development of a robust forecasting scheme linking July Niño-4 SST index and seasonal burned area in SOND. We note that consideration of a longer period-namely, 19502010 - leads also to a strong correlation between SON rainfall and ENSO SST indices (Barbero and Moron 2011).

\section{b. Forecasting the fire frequencies in SOND from Niño-4 in July}

Figure 4a shows the observed and hindcast BANC. The skill (correlation between the observed and simulated $\log$ of BANC) is $0.87^{*}$. The largest error occurs in 2005 , when the MdS fire accounts for $84.6 \%$ of the seasonal total burned area. When that fire is removed from the observations, the skill increases to $0.95^{*}$.

Figure $4 \mathrm{~b}$ shows the correlation between observed and hindcast seasonal burned area. The shortness of the record leads inevitably to a relatively high level of stochastic noise, and close stations could have different levels of skill. Nevertheless, the skill is weaker north of 
Grande Terre and appears to be negative around Nouméa. Cross validation usually amplifies small negative bias (Barnston and van den Dool 1993). Moreover, in the case of Nouméa and its suburbs, a single observation-SOND 2005-accounts for a very large proportion of total variability during a "neutral" ENSO year, at least in July, and this could not be accurately fitted with other observations that have far-smaller burned areas on average. The correlation between PC1 (PC2) and its reconstruction from July Niño-4 SST index [i.e., the standardized values of the $\log$ of predicted burned area projected onto EOF1 (EOF2)] is 0.84* (0.32), suggesting that $\mathrm{PC} 1$ conveys the climatic signal, predictable at seasonal scale.

\section{c. Possible climatic source of spatial modulation of skill}

The correlations between July Niño-4 SST index and SON rainfall anomalies are usually strong (median $=$ $-0.82 *$ across the 43 rain gauges), but weaken slightly on the windward coast and also in the southern part of the leeward coast between Boulouparis and Nouméa (Fig. 5a). These spatial variations are also seen for correlations computed on a longer period (1950-2010, not shown). This map shares some similarity with Fig. 4b, except in the north of Grande Terre, where a high correlation of SON rainfall with July Niño-4 SST index is combined with poor skill of SOND burned area from the July Niño-4 SST index. The correlations between the SON rainfall anomalies and SOND burned area in a radius of $20 \mathrm{~km}$ around each rain gauge are usually moderate (Fig. 5b) and are lower in the south and also in the north of Grande Terre. The scatterplot shown in Fig. $5 \mathrm{c}$ suggests a relationship between the level of skill of burned area from the July Niño-4 SST index and the intensity of the local-scale relationship between SON rainfall anomalies and SOND burned area: the rain gauges for which July Niño-4 SST index performs better to forecast SON rainfall anomalies are also usually those for which the relationship between SOND burned area and SON rainfall anomalies is the largest. In other words, those rain gauges that combine good skill of SON rainfall anomalies from July Niño-4 SST index and poor skill of SOND burned areas either from SON rainfall anomalies or from July Niño-4 SST index are probably the stations at which nonclimatic factors affect the interannual variability of SOND burned areas the most.

Specific results for 2005, which year included the large MdS fire, help to illustrate the possible role of less predictable climatic forcing, at least from the July Niño-4 SST index. Negative rainfall anomalies are widespread in SOND 2005, especially in the southernmost third of (a) SON rainfall \& NINO 4 (July)

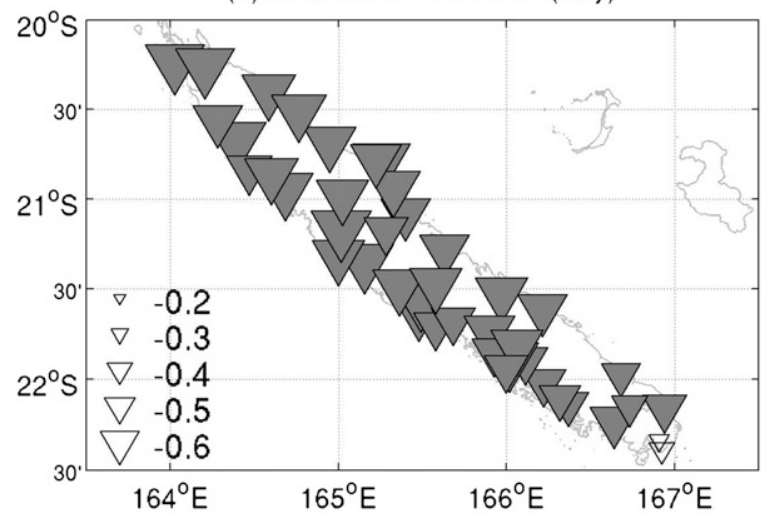

(b) Log(burned area) in SOND \& SON rainfall

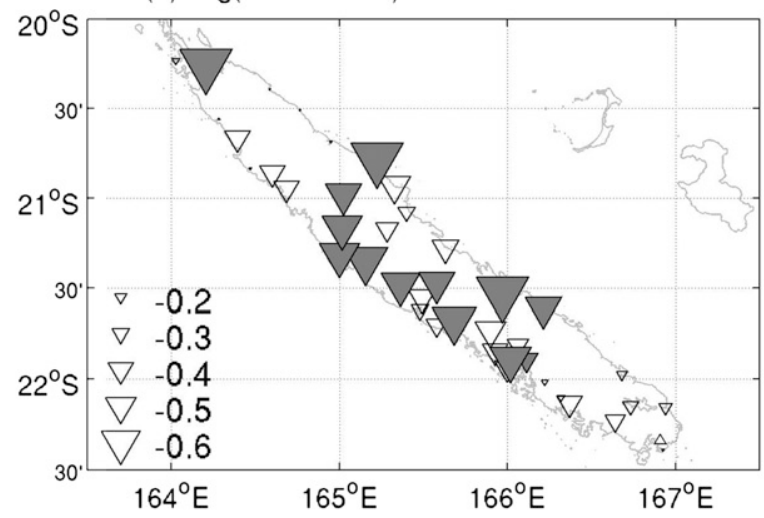

(c) Burned area (SOND), NINO 4 (July) et rainfall (SON)

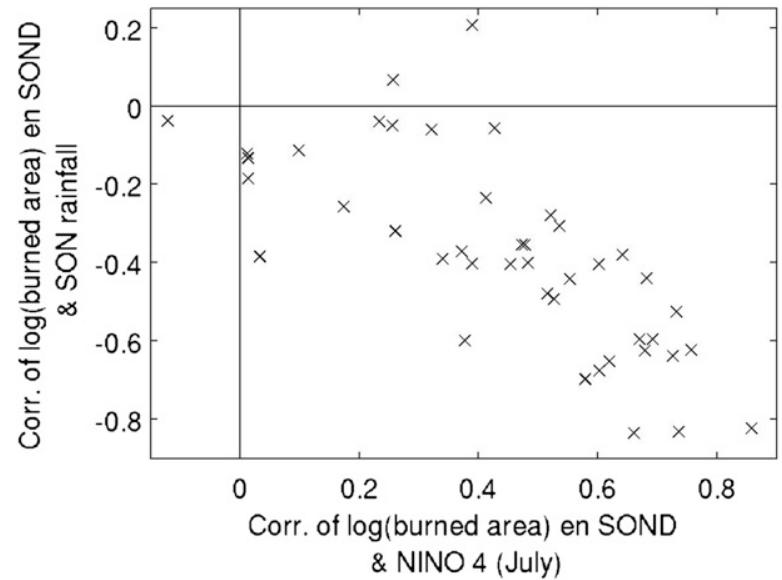

FIG. 5. (a) Correlation between July Niño-4 SST index and SON rainfall. (b) Correlation between the $\log$ of SOND burned area within a radius of $20 \mathrm{~km}$ around 43 rain gauges and SON rainfall. In (a) and (b), upward-pointing (downward pointing) triangles indicate positive (negative) correlations, and gray (open) triangles indicate significant (not significant) correlations at the two-sided $90 \%$ level according to a random-phase (Janicot et al. 1996) test. (c) Scatterplot of the correlation between the log of the observed SOND burned area within a radius of $20 \mathrm{~km}$ around 43 rain gauges and the July Niño-4 SST index (on the abscissa) and the correlation between SON rainfall anomalies and the SOND burned area within a radius of $20 \mathrm{~km}$ around 43 rain gauges (on the ordinate). 
(a) Rainfall anomalies in SOND 2005

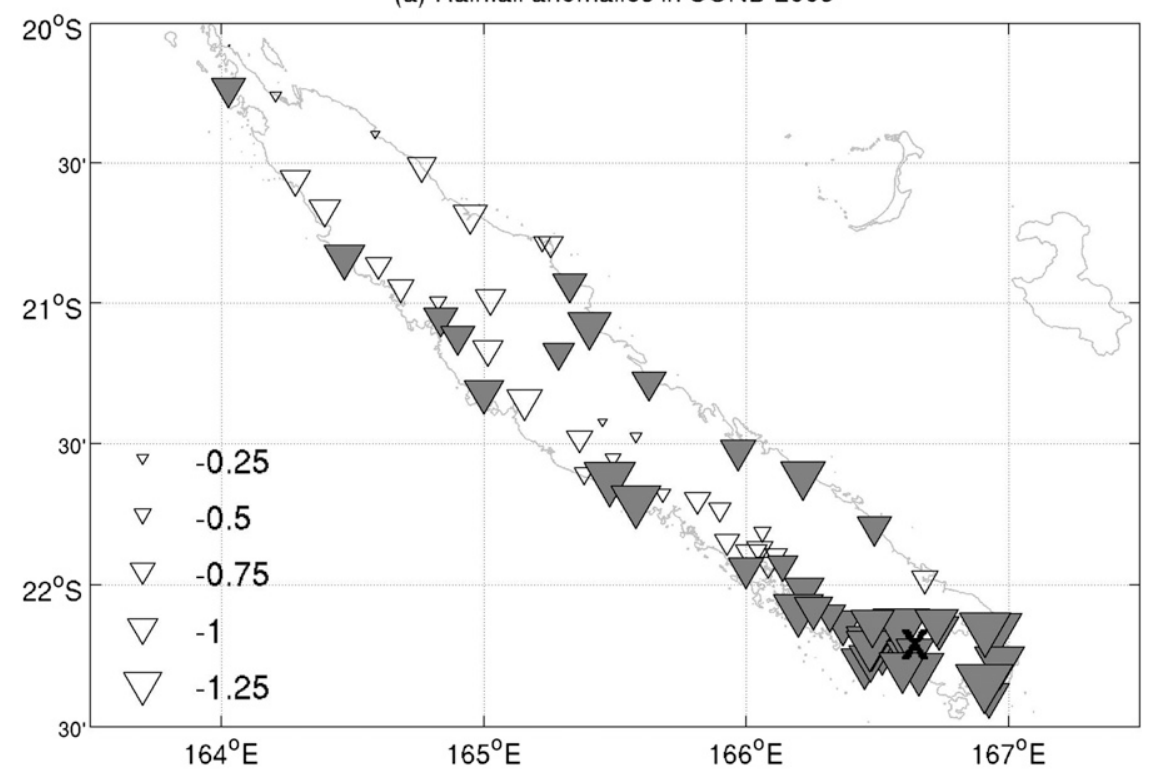

(b) Mean length of dry spell anomalies in SOND 2005

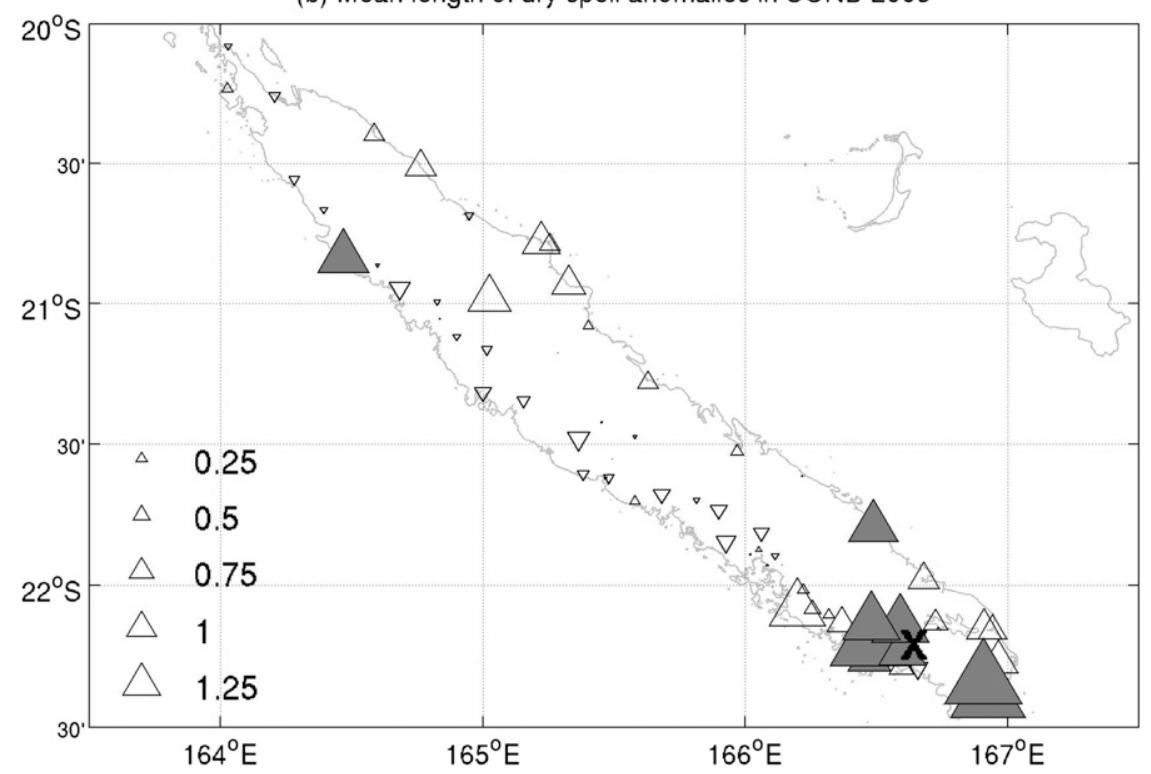

FIG. 6. (a) Standardized anomalies (unit $=$ std dev) of mean rainfall amount in SOND 2005 (relative to the 2000-10 mean). (b) Standardized anomalies (unit = std dev) of mean length of dry spell in SOND 2005 (relative to the 2000-10 mean). The location of the MdS fire in December 2005 (3641 ha) is shown by a cross. In (a) and (b), upward-pointing (downward pointing) triangles indicate positive (negative) anomalies and gray triangles indicate that 2005 has the largest negative anomalies in (a) and positive anomalies in (b) relative to the local 2000-10 climatological mean. The maps are displayed for 70 rain gauges.

Grande Terre (Fig. 6a), whereas Niño-4 SST index is near neutral in July (SSTA $=+0.19^{\circ} \mathrm{C}$ relative to the 2000-10 mean). Figure 6b shows that the seasonal anomalies of mean length of dry spells, defined as consecutive days receiving less than $1 \mathrm{~mm}$ of precipitation, are anomalously positive over a small area south of $22^{\circ} \mathrm{S}$, near the location of the MdS fire. We hypothesize that this specific anomaly, clearly smaller than the spatial scale related to the Niño-4 SST index forcing (Fig. 5a), enhances locally the impact of seasonal negative rainfall anomalies. We also note that the temporal phase of the MdS fire is unusual at the end of December at which 
time temperatures are already summerlike. Note that the mean burned area in December drops from 579 ha (Fig. 1a) to 276 ha when the MdS fire is removed from the database. In summary, the large MdS fire has been favored by a moderate negative rainfall anomaly, enhanced by long dry spells near Nouméa and also by its seasonal occurrence at the end of December. This analysis does not exclude specific human-driven factors.

\section{Conclusions and discussion}

As in most of the tropical zone, fires in New Caledonia peak from the end of the cool/dry season to the start of the warm/wet season when drought, potentially combined with high temperatures, increases the fire risk. Atmospheric conditions, especially rainfall anomalies, are also largely predictable in austral spring from ENSO conditions, which are usually firmly established 3-6 months ahead. This is in some ways an "ideal" context from the seasonal prediction point of view since the predictor (in this case, the July Niño-4 SST index) is highly predictable because of its temporal inertia from May to June and exerts a strong impact on the localscale climatic variable (i.e., SON rainfall), which is also related to the studied impact (i.e., the burned area). Despite the myriad nonclimatic factors that potentially influence the ignition and propagation of fire, the crossvalidated prediction of SOND total area from the July Niño-4 SST index is very accurate, even when this prediction is slightly decreased (from a correlation of 0.95 to one of 0.87 between observed and simulated log of BANC) by the exceptional MdS fire in December of 2005. This prediction scheme benefits from very high correlations between July Niño-4 SST index and the rainfall anomalies in SON that follow. The correlation between a spatial average of SON rainfall anomalies and July Niño-4 SST index is $-0.90^{*}$, and the correlation between these latter anomalies and $\log$ of BANC is $r=-0.96^{*}$.

The prediction skill for SOND burned areas decreases at local scale since specific factors tend to blur the climatic signal related to the ENSO phenomenon. The spatial variations in skill put most of the central part of Grande Terre in opposition to its northern part and also Nouméa and its suburbs (Fig. 4b). We should keep in mind that Nouméa is the only town on NC with more than 100000 inhabitants, whereas Bourail-the main town outside Nouméa and its suburbs-has less than 5000 inhabitants. Most of the spatial variations appear to be poorly related to the variation of the ENSO teleconnection itself. The ENSO phenomenon is a global-scale feature and leads to large-scale anomalies even if the signal seems to decrease southward and also along the windward coast (Fig. 5a). Warm ENSO events, especially those peaking near the date line, are associated with anomalous anticyclonic conditions and stronger east-southeast winds than usual (Barbero and Moron, 2011). The decrease in skill around Nouméa is also heavily affected by the exceptionally large MdS fire, which occurred at the end of December of 2005-that is, outside the main central Pacific warm events - and apparently is related to very long dry spells restricted to southern NC (Fig. 6b). The decrease of skill in the north seems to be mostly related to nonclimatic factors, since strong predictive skill of local-scale rainfall from the Niño-4 SST index does not translate into high skill for the burned areas, which appear to be unrelated to local-scale rainfall.

Overall, the correlations among SOND burned areas, SON rainfall anomalies, and July Niño-4 SST index are very high. We note, however, the short 11-yr period of the record for the availability of hot spots detected by the MODIS satellite. Nevertheless, the cross validation between the July Niño-4 SST index and the burned area in SOND does not critically degrade the skill (Figs. $4 a, b)$. Moreover, the correlation relies on well-known physical relationships linking central Pacific warm ENSO events and southwestern Pacific atmospheric anomalies from austral winter to austral summer (e.g., Morlière and Rébert 1986; Vincent 1994; Nicet and Delcroix 2000; Fischer et al. 2004; Barbero and Moron 2011; Vincent et al. 2011). In that context, Barbero and Moron (2011) demonstrated also that the correlation between SON rainfall anomalies in NC and Niño-4 SST index increases after 1980, in accordance with a slow warming near the date line. It is possible that this longterm warming trend amplifies the prediction skill for SOND burned area from the July Niño-4 SST index during the recent period.

Beyond inherent sampling uncertainty due to the shortness of available satellite records, at least two additional reasons could artificially increase the correlations among July Niño-4 SST index, SON rainfall anomalies, and SOND burned areas. Although we lack supportive scientific survey results, anecdotal evidence suggests that, first, humans could ignite fires more frequently when climate conditions are drier than usual. More important, however, anomalous seasons could be related to abnormal cloud cover. For example, warm central Pacific ENSO events leading to a drier-thanusual season should be logically associated with less cloud cover than usual. Consequently, the relative fraction of fire recorded by satellites may be higher during drier seasons/warm ENSO events, thus enhancing the climatic signal. We do not have any continuous and systematic record of cloudiness across $\mathrm{NC}$ but the mean length of wet spells (i.e., number of consecutive day receiving at least $1 \mathrm{~mm}$ ) is a proxy for an upper limit 
of continuous cloud cover. It appears that the mean length of wet spells is 1.8 days (for SOND 2000-10 averaged over the 70 rain gauges) and the spatial average of interannual local-scale standard deviations is only 0.3 days (2.3 days for dry spells). This result suggests that the time interval between two successive cloud-free periods is probably not too different between anomalous wet and dry SOND seasons. This climatological argument associated with the cross-checking of MODIS hot spots with MOD13Q1/ETM + vegetation changes (see section 2a) supports our view that possible cloud contamination may not radically bias our main result.

Acknowledgments. This study is funded by a grant from ANR under the INC program (Grant ANR-07BDIV-008). The meteorological data are extracted from the Météo-France database with the kind help of Y. Bidet (Météo-France; Aix en Provence) and Y. Noack (CEREGE). We also thank the editor (S. Yuter) and the three anonymous reviewers, who helped us to clarify the initial version of this paper. Last, we thank A. Goodwillie (Lamont-Doherty Earth Observatory of Columbia University) for his careful proofreading of the revised version of this paper.

\section{REFERENCES}

Ashok, K., S. K. Behera, S. A. Rao, H. Weng, and T. Yamagata, 2007: El Niño Modoki and its possible teleconnections. J. Geophys. Res., 112, C11007, doi:10.1029/2006JC003798.

Balmaseda, M. A., M. K. Davey, and D. L. T. Anderson, 1995: Decadal and seasonal dependence of ENSO prediction skill. J. Climate, 8, 2705-2715.

Barbero, R., and V. Moron, 2011: Seasonal to decadal modulation of the impact of El Niño/Southern Oscillation on New Caledonia (SW Pacific) rainfall. J. Geophys. Res., 116, D23111, doi:10.1029/2011JD016577.

_ — - M. Mangeas, M. Despinoy, and C. Hély, 2011: Relationships between MODIS and ATSR fires and atmospheric variability in New Caledonia (SW Pacific). J. Geophys. Res., 116, D21110, doi:10.1029/2011JD015915.

Barnston, A. G., and H. M. Van den Dool, 1993: A degeneracy in cross-validated skill in regression-based forecasts. J. Climate, 6, 963-977.

Bouchet, P., T. Jaffré, and J. M. Veillon, 1995: Plant extinction in New Caledonia: Protection of sclerophyll forests urgently needed. Biodiversity Conserv., 4, 415-428.

Chevalier, L., 1996: Terre de Fer et de Jade: De la Baie de Prony à l'île Ouen. Editions du Cagou, 149 pp.

Ebisuzaki, W., 1997: A method to estimate the statistical significance of a correlation when the data are serially correlated J. Climate, 10, 2147-2153.
Fischer, M., B. Dewitte, and L. Maîtrepierre, 2004: A non-linear statistical downscaling model: El Niño/Southern Oscillation impact on precipitation over New Caledonia. Geophys. Res. Lett., 31, L16204, doi:10.1029/2004GL020112.

Gedalof, Z., D. L. Peterson, and N. J. Mantua, 2005: Atmospheric, climatic, and the ecological controls on extreme wildfire years in the northwestern United States. Ecol. Appl., 15, 154-174.

Giglio, L., I. Csiszar, and C. O. Justice, 2006: Global distribution and seasonality of active fires as observed with the Terra and Aqua Moderate Resolution Imaging Spectroradiometer (MODIS) sensors. J. Geophys. Res., 111, G02016, doi:10.1029/ 2005JG000142.

Gillespie, T. W., and T. Jaffré, 2003: Tropical dry forests in New Caledonia. Biodiversity Conserv., 12, 1687-1697.

Jaffré, T., P. Bouchet, and J. M. Veillon, 1998: Threatened plants of New Caledonia: Is the system of protected areas adequate? Biodiversity Conserv., 7, 109-135.

Janicot, S., V. Moron, and B. Fontaine, 1996: ENSO and Sahel drought. Geophys. Res. Lett., 22, 1701-1704.

Kao, H. Y., and J. Y. Yu, 2009: Contrasting eastern Pacific and central Pacific types of ENSO. J. Climate, 22, 615-632.

Kaplan, A., M. A. Cane, Y. Kushnir, A. C. Clement, M. Benno Blumenthal, and B. Rajagopalan, 1998: Analyses of global sea surface temperature 1856-1991. J. Geophys. Res., 103, 18 56718589.

Le Page, Y., J. M. C. Pereira, R. Trigo, C. Da Camara, D. Oom, and B. Mota, 2008: Global fire activity patterns (1996-2006) and climatic influence: An analysis using the World Fire Atlas. Atmos. Chem. Phys., 8, 1911-1924.

McCoy, S., T. Jaffre, F. Rigault, and J. E. Ash, 1999: Fire and succession in the ultramafic maquis of New Caledonia. J. Biogeogr., 26, 579-594.

Michaelsen, J., 1987: Cross-validation in statistical climate forecast models. J. Climate Appl. Meteor., 26, 1589-1600.

Morlière, A., and J. P. Rébert, 1986: Rainfall shortage and El Niño-Southern Oscillation in New Caledonia, southwestern Pacific. Mon. Wea. Rev., 114, 1131-1137.

Myers, N., R. A. Mittermeier, C. G. Mittermeier, G. A. B. da Fonseca, and J. Kent, 2000: Biodiversity hotspots for conservation priorities. Nature, 403, 854-858.

Nicet, J. B., and T. Delcroix, 2000: ENSO-related precipitation changes in New Caledonia, southern Pacific: 1969-98. Mon. Wea. Rev., 128, 3001-3006.

Roy, D. P., L. Boschetti, C. O. Justice, and J. Ju, 2008: The collection 5 MODIS burned area product-Global evaluation by comparison with the MODIS active fire product. Remote Sens. Environ., 112, 3690-3707.

Van der Werf, G. R., and Coauthors, 2008: Climate regulation of fire emissions and deforestation in equatorial Asia. Proc. Natl. Acad. Sci., 105, 20 350-20 355.

Vincent, D. G., 1994: The South Pacific convergence zone (SPCZ): A review. Mon. Wea. Rev., 122, 1949-1970.

Vincent, E. M., M. Lengaigne, C. E. Menkes, N. C. Jourdain, P. Marchesiello, and G. Madec, 2011: Interannual variability of the South Pacific convergence zone and implications for tropical cyclone genesis. Climate Dyn., 36, 1881-1896. 